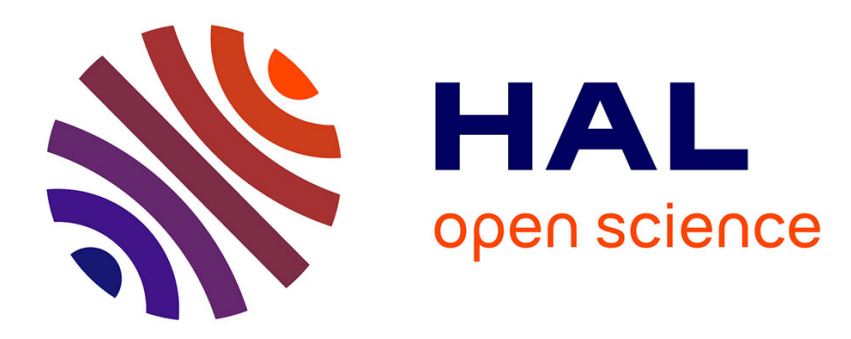

\title{
Investment Sensitivity to Inter-enterprises Payment Deadlines
}

\author{
Aissata Boubacar Moumouni
}

\section{To cite this version:}

Aissata Boubacar Moumouni. Investment Sensitivity to Inter-enterprises Payment Deadlines. 2020. hal-02889436

\section{HAL Id: hal-02889436 https://hal.science/hal-02889436}

Preprint submitted on 3 Jul 2020

HAL is a multi-disciplinary open access archive for the deposit and dissemination of scientific research documents, whether they are published or not. The documents may come from teaching and research institutions in France or abroad, or from public or private research centers.
L'archive ouverte pluridisciplinaire HAL, est destinée au dépôt et à la diffusion de documents scientifiques de niveau recherche, publiés ou non, émanant des établissements d'enseignement et de recherche français ou étrangers, des laboratoires publics ou privés. 


\title{
Investment Sensitivity to Inter-enterprises Payment Deadlines*
}

\author{
Aissata BOUBACAR MOUMOUNI ${ }^{\dagger}$
}

May 2019

\begin{abstract}
This paper investigates the determinants of firms investment financing constraints. Using an endogenous switching regression model on French ProvenceAlpes Côte d'Azur region firms data collected between 2005-2014, we provide a novel evidence of the role of inter-enterprises payment deadlines which are days of sales outstanding and suppliers payment terms, as factors determining firms investment financing constraints. We also show that there is a non-negligible number of firms switching each year either from constrained regime to unconstrained regime or unconstrained regime to constrained one. By developing a model, we highlight the factors determining firms regime change.
\end{abstract}

Keywords: Firms Investment, Inter-enterprises Payment Deadlines, Endogenous Switching Regression Model.

JEL codes: G30, G32, C30, C33

*I deeply thank my PhD supervisors, Prof Mohamed Belhaj and Prof. Vêlayoudom Marimoutou for their guidance and support. I acknowledge the financial support of the Provence-Alpes Côte d'Azur regional council and Finances \& Mediterranean Council.

${ }^{\dagger}$ Aix-Marseille Univ., CNRS, EHESS, Centrale Marseille, AMSE, Marseille, France; Email: aissata.boubacar-moumouni@univ-amu.fr; Address: 5 boulevard Bourdet, 13001 Marseille, France. 


\section{Introduction}

Modigliani and Miller (1958) [23] launched the debate on the relationship between financing constraints and investment. Assuming perfect capital market, they defend the perfect subtitutability between internal and external financing leading to the independence of firms investment from their financing decisions. The reality is however reflected by different markets frictions such as informational asymetry on access to external funds, making capital markets imperfect. Consequently, some firms could face external financing constraints and their investment could be limited to their internal funds. As a result, internal and external financing are not perfect substitutes and the amount of internal funds could be an important determinant of investment. Since then, an abondant literature has studied the determinants of financing constraints on firms investment by investigating the sensitivity of investment to cash flow. Cash flow is defined in the literature as the sum between the net profit and the depreciation. This definition does not consider an important element: the business to business credits (B2B credits). B2B credits represent firms receivables from their customers and the debts to their suppliers, and could represent significant financing sources for firms.

This paper aims to contribute to the existing literature by considering B2B credits as a part of the cash flow and investigate their impact on firms investment. B2B credits generate inter-enterprises payment deadlines which are days of sales outstanding and suppliers payment terms. Therefore, we consider that it is more relevant to study directly the impact of inter-enterprises payment deadlines on firms investment. For a better interpretation of our results, we also controlled for the cash flow as defined in the literature.

Our second contribution is empirical. When investigating the sensitivity of investment to inter-enterprises payment deadlines, we follow the general strategy used by researchers. They consider that capital market imperfections must be studied by comparing its differential effect on the investment of firms classified in constrained and unconstrained groups. In this paper, we used the accelerator approach of the endogenous switching regression model providing estimates of separate investment regressions without a priori classification of firms in constrained or unconstrained regime. However, the firms can not be fixed in one regime over the period. Yet, the model does not specify to the researcher the proportions of firms that change regime each year during the period and the determinants of the firms regime change. We develop for the first time a model for this purpose.

In this paper, we consider a database containing accounting informations on French Provence-Alpes Côte d'Azur region firms between 2005-2014. In this region, 99\% of firms are Small and Medium Enterprises (SMEs). Our third contribution is 
that this study is conducted on SMEs. It allows to provide a new index of financing constraints for the latter. Indeed, a large majority of papers related to financing constraints in the existing literature concerns large firms. These categories of firms are often less concerned by the information asymmetries than SMEs.

Our findings on the determinants of firms investment are the following. First, our results on the investment cash-flow sensitivity are consistent with the result of Fazzari et al.(1988) [12] where the cash flow impact on investment is significant and increasing with the constraint status of the firms. Second, our results provide the evidence that inter-enterprises payment deadlines impact significantly firms investment. The investment is positively sensitive to suppliers payment terms whereas it is negatively sensitive to the days of sales outstanding. The constrained firms investment is more sensitive to the days of sales outstanding and suppliers payment terms than the unconstrained firms investment. These results confirm the regional entrepreneurs statements. Indeed, when meeting them and discussing with them about the challenges they encounter, they mostly talk about days of sales outstanding and suppliers payment terms. Furthermore, we also exploit the selection equation to analyse the proportions of unconstrained and constrained firms per year during the period of study. These proportions are not constant over time. There is a non-negligible number of firms changing regime each year from unconstrained to constrained or constrained to unconstrained regime. Through the model we develop in order to learn more about the factors determining firms regime change, we found that tangibility, leverage, financial autonomy, and the soft budget constraint are the factors influencing significantly unconstrained firms movement to the constrained regime. In parallel, tangibility, leverage, financial autonomy, long-term debt, size, and soft budget constraint are the factors impacting significantly constrained firms movement to the unconstrained regime.

The rest of the paper is organized as follows: Section 2 provides a brief review of the past literature on the determinants of firms investment financing constraints, particulary the cash-flow which was widely studied. Section 3 explains the methodology of the endogenous switching regression model. Section 4 presents and describes in detail the data used in order to give a representive view of Provence-Alpes Côte d'Azur firms. Section 5 gives the empirical results and also outlines a key description of the constrained and the unconstrained groups per year as well as the factors making a firm to change regime. Finally, section 5 concludes.

\section{Related Literature}

The body of research devoted to the effect of financing constraints on firms investment is mainly focused on the investment-cash flow sensitivity. It is composed of 
two kind of research ideas: empirical and therotical evidences. Theoritical research began with Modigliani and Miller (1958) [23] defending the irrelevance of firm's capital structure on its investment decisions under perfect capital markets. However, in reality, there are several markets frictions making capital markets imperfect, such as informational asymetry or agency problems. Consequently, certain firms faced difficulties to access to external financing. As a result, the cost of external financing could become higher than the cost of internal financing and the level of internal financing could be an important determinant of investment empirically speaking. Since then, Fazzari et al.(1988) [12] study the impact of financial constraints on firms investment decisions by assessing the effect of cash-flow on firms investment. Using dividend payout, they split their sample into constrained and unconstrained firms ${ }^{1}$ and found that constrained firms investment are more sensitive to cash flow than unconstrained firms investment. Fazzari et al.(1988) [12] find support in a number of subsequent papers (Hoshi et al.(1991) [16], Whited(1992) [33], Bond and Meghir(1994) [6], and Carpenter et al.(1994)). In 1997, Kaplan and Zingales [22] questionned Fazzari et al.(1988) [12] results and demonstrated that the investment sensitivity to cash flow is higher for unconstrained firms than for constrainted firms. These findings were further supported in 1999 by Cleary [9]. Some contributions try to explain these inconsistent findings in the literature. Using two different classification criteria, Moyen (2004) [24] showed that the unconstrained firms investment-cash flow sensitivity could be higher or lower than the constrained firms investment cash flow sensitivity depending on the classification criteria used. Gianni La Cava (2005) [13] distinguishes financially distressed firms from financially constrained firms. He demonstrated that the presence of financially distressed firms appears to bias downwards the constrained firms investment-cash flow sensitivity and showed that the estimated sensitivility degree appears to be the same for both groups.

Nevertheless, in the literature, the cash flow, is calculated as the sum of the net profit and depreciation. A such definition does not consider the B2B credits. They are significant alternative sources of financing between firms. In this paper, our approach consists of considering the B2B credits payment terms, the days of sales outstanding and suppliers payment delays, in addition to the cash flow and evaluate their impacts on firms investment.

To address the investment-cash flow sensitivity theoritical debate, recent research stressed on empirical evidence. The discussed strand concerns the firms classification into constrained and unconstrained groups. Since the first papers in these areas, research are conducted by splitting firms into subgroups according to their constraint status. Fazzari et al. (1988) [12], Kaplan and Zingales (1997) [22] and other papers used a prior firms classification method to split their sample into constrained and

\footnotetext{
${ }^{1}$ Constrained firms are firms that have no dividend payout.
} 
unconstrained groups. The problem of this technique is the static mysclassification it can cause but also the selection criteria can be correlated to the endogenous variable. It may also cause a dynamic mysclassification, the firm position or situation may evolve over the sample especially when the study period is long. Schiantarelli (1998) [19] was the first to attempt to adress the misspecification effect by using an endogenous switching regression model. With this model the firms groups are determined endogenously by a selection equation.

Nonetheless, within the existing literatures using the endogenous switching regression model, none exploits the selection equation. The model defines two groups of firms that differ according to their investment behavior but does not automatically specify to the researcher the firms changing regime accross the period as well as the factors determining the firms status change. Our paper is the first to extend the selection equation by developing a theoritical model for this purpose.

\section{Empirical strategy}

This paper studies the effect of the inter-enterprises payment deadlines on firms investment. Conducting an empirical study, we follow Schiantarelli (1998) [19] and use an endogenous switching regression model for our estimation. Considering a firm $i$ at time $t$, the model is constitued by the following three equations:

$$
\begin{gathered}
I_{1 i t}=\beta_{1} X_{i t}+\epsilon_{1 i t} \\
I_{2 i t}=\beta_{2} X_{i t}+\epsilon_{2 i t} \\
y_{i t}^{*}=\alpha Z_{i t}+\nu_{i t}
\end{gathered}
$$

Equations 1 and 2 are the structural equations that describes the firms investment behavior in the regimes. $I_{1 i t}$ and $I_{2 i t}$ are the investment spending of two firms $i$ at time $t$ respectively in regime 1 and 2. $X_{i t}$ represents the determinants of firms investment. $\beta_{1}, \beta_{2}$ are vectors of parameters, $\epsilon_{1}, \epsilon_{2}$ the vectors of error terms.

Equation 3 is the selection equation. The dependent variable, $y_{i t}^{*}$, determines for each firm $i$ at time $t$, its likelihood of being in regime 1 or regime 2. In this paper, the two regimes considered are the unconstrained and constrained regimes. Therefore, the firms likelihood to be in regime 1 or 2 will be determined according to the severity of informational asymetry it faces. The selection process is the following. Consider $I_{1 i t}$ and $I_{2 i t}$ respectively the investment spending of unconstrained and constrained firms. $I_{1 i t}-I_{2 i t}$ is the difference between unconstrained and constrained firms investment spending. This difference is the consequence of the severity of 
informational asymetry. Thus, when there is no informational asymetry, there will be no financial constraints and all the firms will have the same investment spending. Then, $I_{1 i t}-I_{2 i t}=y_{0 i t}^{*}=0$. When a firm i faces informational asymetry at time t causing its financial constraint, its investment $I_{i t}$ is lower than an unconstrained firm investment : $I_{i t} \leq I_{1 i t} \Longrightarrow I_{i t}-I_{2 i t} \leq I_{1 i t}-I_{2 i t}$. Yet, $I_{i t}$ corresponds to the investment of a constrained firm. So, $I_{i t}-I_{2 i t}=0$, and $I_{1 i t}-I_{2 i t}=y_{i t}^{*} \geq y_{0 i t}^{*}=0$. Inversely, a firm i is unconstrained at time $\mathrm{t}$ if its investment $I_{i t}$ is larger than a constrained firm investment, meaning $I_{i t}>I_{2 i t} \Longrightarrow I_{i t}-I_{1 i t}>I_{2 i t}-I_{1 i t}$. $I_{i t}$ corresponds to the investment of an unconstrainted firm. So $I_{i t}=I_{1 i t}$ and $0>$ $I_{2 i t}-I_{1 i t} \Longrightarrow I_{1 i t}-I_{2 i t}=y_{i t}^{*}<y_{0 i t}^{*}=0$. Thus, the firm $i$ will be in the unconstrained regime at time $t$ if $y_{i t}^{*}<0$ with an investment behavior such as $I_{i t}=I_{1 i t}$. Inversely, the firm $i$ will be in the constrained regime at time $t$ if $y_{i t}^{*} \geq 0$ with an investment behavior such as $I_{i t}=I_{2 i t}$.

The set of the selection equation independent variables, $Z_{i t}$, is expressed as a vector of firms characteristics that is associated with its constraint status.

The parameters in the three equations are estimated via maximum likelihood. For the estimation of those parameters, it is assumed that $\epsilon_{1 i t}, \epsilon_{2 i t}$ and $\nu_{i t}$ are jointly normally distributed with mean 0 and covariance matrix $\sum$ that allows for non zero correlation between the shocks to investment and the shocks to firms characteristics:

$$
\sum=\left[\begin{array}{ccc}
\sigma_{1}^{2} & \sigma_{12} & \sigma_{1 \nu} \\
\sigma_{21} & \sigma_{2}^{2} & \sigma_{2 \nu} \\
\sigma_{\nu 1} & \sigma_{\nu 2} & \sigma_{\nu}^{2}
\end{array}\right]
$$

The main advantage of this model is its ability to control for multiple indicators that jointly determine the group in which a firm is likely to belong without the need to split the sample into many smaller parts. In addition, the model simultaneously estimates the equation that predicts (or selects) the constraint status of the firms and the investment behavior of constrained and unconstrained firms.

\subsection{Empirical specifications}

This section specifies the model we estimated. We use Hobdari et al.(2009) [15] approach of the endogenous swithing regression model for our model specifications.

\subsubsection{Investment equations}

The investment equations in the two regimes are the following.

For the unconstrained regime: 


$$
\begin{aligned}
(I / K)_{i t}^{U}= & \left.a_{1} \text { Sales }_{i t-1} / K_{i t-1}\right)+b_{1} \text { CashFlow }_{i t-1}+c_{1} \text { DSO }_{i t-1} \\
& +d_{1} \text { SPT }_{i t-1}+e_{1} \text { Tangibility }_{i t-1}+f_{1} D_{1 i t-1} \\
& +g_{1} D_{2 i t-1}+h_{1} D_{3 i t-1}+\varphi_{i}+\tau_{t}+\epsilon_{1 i t}
\end{aligned}
$$

For the constrained regime:

$$
\begin{aligned}
(I / K)_{i t}{ }^{C}= & \left.a_{2} \text { Salesit-1 }_{i t} / K_{i t-1}\right)+b_{2} \text { CashFlow }_{i t-1}+c_{2} \text { DSO }_{i t-1} \\
& +d_{2} S P T_{i t-1}+e_{2} \text { Tangibility }_{i t-1}+f_{2} D_{1 i t-1} \\
& +g_{2} D_{2 i t-1}+h_{2} D_{3 i t-1}+\varphi_{i}+\tau_{t}+\epsilon_{2 i t}
\end{aligned}
$$

Except the parameters, the two investment equations have the same components. The dependent variables correspond to firms investment in fixed capital (reconstruction, expansion and acquisition of buildings, constructions of new buildings and other business related projects). It is calculated as the ratio of the new amount of fixed capital between the begining and the end of a year and the lagged capital stock. The set of independent variables includes the cash flow, sales, days of sales outstanding and suppliers payment terms, the tangibility and three dummy variables. We calculated the cash flow in line with the existing literature, as the sum of the net profit after taxes and the depreciation expenses. The sales revenue corresponds to the firm total sales revenue per year. This variable is controlled because we expressed the relationship between the investment and the cash flow, days of sales outstanding and suppliers payment terms by using the accelerator-sales approach. This approach supposes that sales could summarize investment opportunities. The investment is supposed to be an increasing function of sales. We expect a positive sign for the latter. The tangibility ratio is calculated as the ratio between tangible assets and total assets. Tangible assets decrease the firms default risks. The higher the firms tangibility ratio, the higher its luck to get external funding for investment. We excepted that the assets tangibility will have a positive impact on firms investment. The use of this variable derives from its use in the selection equation as initial guess (see section 3.1.2). The days of sales outstanding (DSO) correspond to the ratio between the firm receivables and its annual sales revenue, multiplied by 360 days. They correspond to the number of days between the delivery of goods or performance of a service and the collection of the related payments. The suppliers payment terms (SPT) are the ratio between the firm payables and purchases, multiplied by 360 days. They are the average payment terms to the suppliers. We expect firms investment to be decreasing with days of sales outstanding and increasing with suppliers pay- 
ment terms. The investment sensitivity to the inter-enterprises payment deadlines are expected to be larger in the constrained regime than in the unconstrained regime in absolute value. D1, D2, D3 correspond to dummies calculated respectively as the product between the initial guess (see section 3.1.2) and respectively the cash flow, days of sales outstanding, and suppliers payment terms. They are included to control for the tangibility effect on the investment-cash flow, investment-days of sales outstanding, investment-suppliers payment terms sensitivities. Finally, $\varphi_{i}$ and $\tau_{t}$ represent respectively sector and year fixed effects.

\subsubsection{Selection equation}

The selection equation determines endogenously the firms likelihood of being in the constrainted or unconstrained regime. The selection equation we estimated is the following.

$$
\begin{gathered}
y *_{i t}=\kappa \text { Size }_{i t}+\rho \text { Age }_{i t}+\beta \text { Tangibility }_{i t}+\text { rleverage }_{i t}+\vartheta S B C_{i t}+ \\
\omega \text { RatioFinAutonomy }_{i t}+\alpha \text { Longtermdebt }+\nu_{i t}(5)
\end{gathered}
$$

The dependent variable, $y_{i t}^{*}$, proxy the severity of informational asymetry for each firm $i$ at time $t$. Although the severity of informational asymetry is unknown by the researcher. Only firms characteristics are observed. To overcome this, $y *_{i t}$ is expressed as a latent variable measuring the firms likelihood to be in the constrained or unconstrained regimes. For the estimation we must give an initial guess for this variable also called the classification variable. In this paper, we follow the approach of Almeida et al.(2007) [?] and use assets tangibility as initial guess. They assume that tangible firms are less exposed to informational asymetry because tangible assets can be set as collateral and this decreases the firms default risks and increases its ability to get external funds. In this paper, we take the median as threshold and assume that a firm having a tangibility ratio more than the median tangibility ratio is more likely to be financially unconstrained and a firm having a tangibility ratio larger than the median tangibility ratio is more likely to be unconstrained. The observation will be coded 1 if the firm tangibility ratio is larger than the median tangibility ratio and 0 if not. To address potential biases in the results, we made robustness check of the initial guess (see section 4.4).

Firms classification in the constrained or the unconstrained group is influenced by the set of selection equation independent variables ${ }^{2}, Z_{i t}$, named the selection vector. In this work, some variables of the selection vector come from the existing

\footnotetext{
${ }^{2}$ It's composed by a set of firms multiple characteristics.
} 
literature but we add some variables that we think are important. The selection vector includes first the firms size. The size is proxy by the employees number per year. It has the advantage of being insensitive to inflation. Second, we use firms age which is a non-negligible firm characteristic. The tangibility is controlled in the three equations of the model because of its role as initial guess. It's calculated as the ratio between the tangible assets and the total assets. The leverage is measured as the ratio between the total debt and the debt plus equity. The Soft Budget Constraint $(S B C)$ is a dummy variable taking 1 if the firm has a negative EBITDA but receives positive financial debt. The ratio of financial autonomy is calculated as the ratio between the equity and financial debt. The Long term debt referes to the gross financial debt.

We expect positive signs for the size, age, tangibility, $S B C$, ratio of financial autonomy and a negative sign for the long term debt. At the moment, we can not predict the leverage sign because there is not a main consensus in the literature about it. When a firm has a high or low leverage, it can sometimes be interpreted differently according to whether or not it is the firm choice to renonce to debt or to use more debt (Hovakimian (2009) [18]).

\section{Data}

Our sample is collected from Diane ${ }^{3}$ database constructed by Bureau Van Dijk. It includes annual informations on French PACA Region non-financial firms over 20052014. They are the only data we can access. The data base is such that firms have at least one employee. We adjusted the data base to get our final sample because an estimation with the raw data gives non-significant results. Potential outliers and unexpected data were dropped out of $1 \%$ and $99 \%$ percentiles of all variables. In addition, observations having days of sales outstanding and suppliers payment terms higher than 360 days were deleted as well as firms with tangibility ratio larger than 1. Finally, we get an unbalanced panel of 122746 observations over the whole period. The firms are from eighty different sectors according to the second level subdivision of the French Classification of Activities (NAF rev.2) by INSEE. Table 1 reports the descriptive statistics of the variables used.

\subsection{Descriptive statistics}

Table 1 gives a general description of the key variables by giving their mean and their standard deviations. PACA Region firms are on average 13 years old. An average firm has 8 employees and invests around $17 \%$ of its capital stock each year.

\footnotetext{
${ }^{3}$ This database covers the majority of French companies (more than 1,3 Millions firms) required to file their annual financial accounts.
} 
Firms investment was not stable accross the period. It was increasing between 20092010 and decreasing between 2006-2008 and 2011-2014. The tangible assets of an average firm represent around $34 \%$ of its total assets. Table 1 shows also that interenterprises payment deadlines have decreased during the period of study, especially after the 2008 financial crisis. An average firm collected payments from its customers in 39 days in 2006 compared to 35 days in 2014. In parallel, the suppliers were paiyed in 71 days in 2006 compared to 51 days in 2014 . 


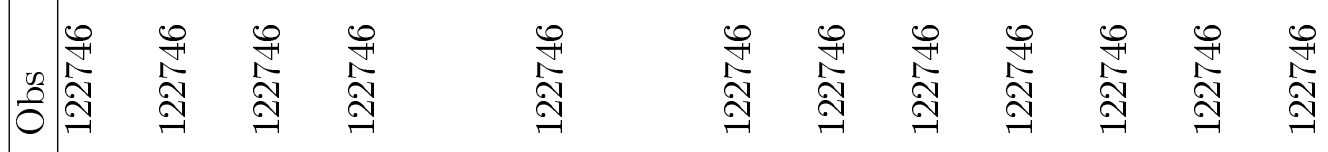

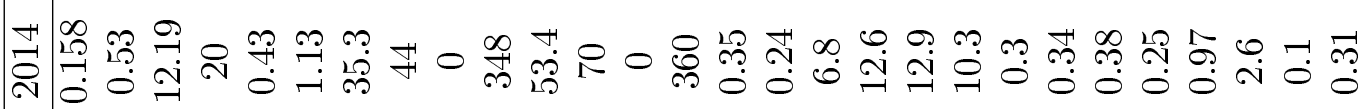

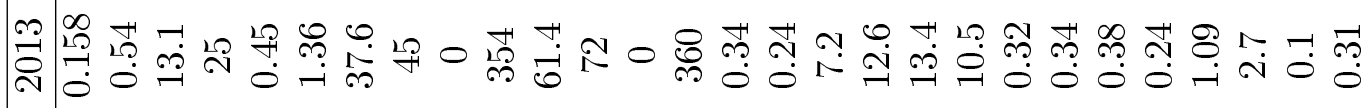

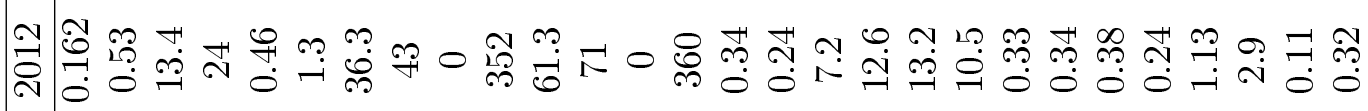

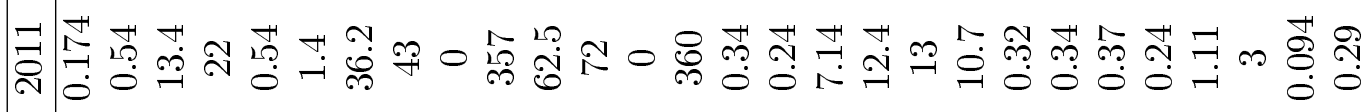

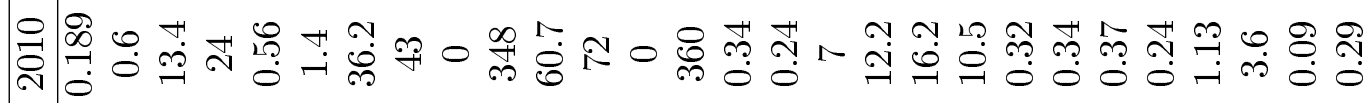
零蛋

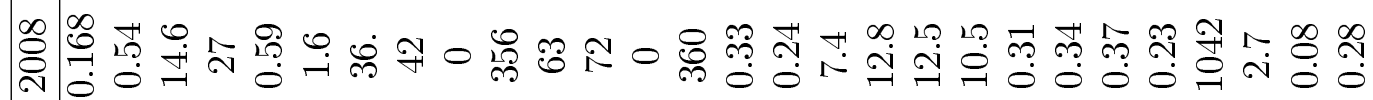

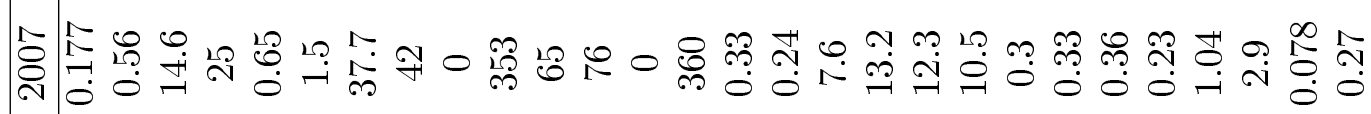

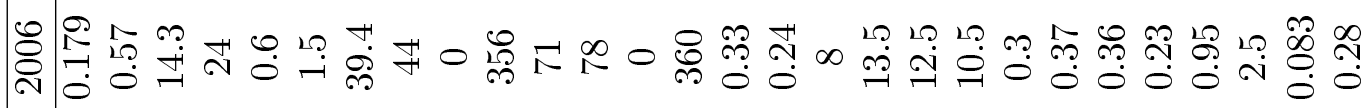

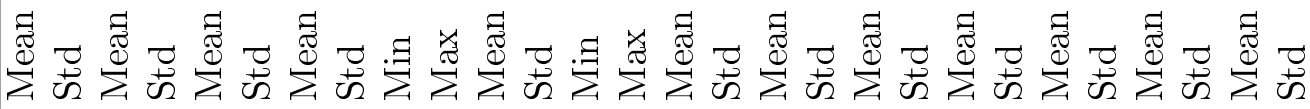

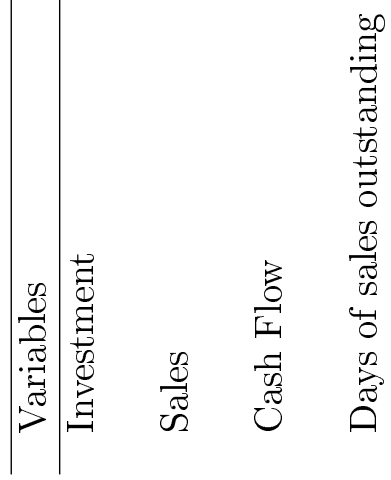

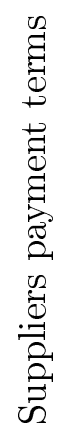

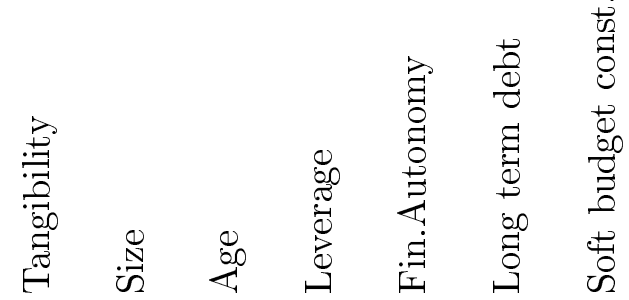


Figure 1 details the distributional characteristics of the inter-enterprises payment deadlines by year over the period. We remark that except in 2006 , the $25^{\text {th }}$ percentile of the days of sales outstanding and suppliers payment terms is approximatively equal to zero. It means that from 2007 to 2014 , at least $25 \%$ of firms cashed their customers and payed their suppliers immediately.

In 2006, the median of the days of sales outstanding and suppliers payment terms are respectively 26 and 52 days compared to 20 and 31 days in 2014 . The third quartile of the days of sales outstanding and suppliers payment terms are respectively 63 and 110 days in 2006 against 55 and 79 days in 2014 meaning that at least $25 \%$ of the firms cashed their customers in more than 55 days and $25 \%$ payed their suppliers in more than 79 days in 2014.

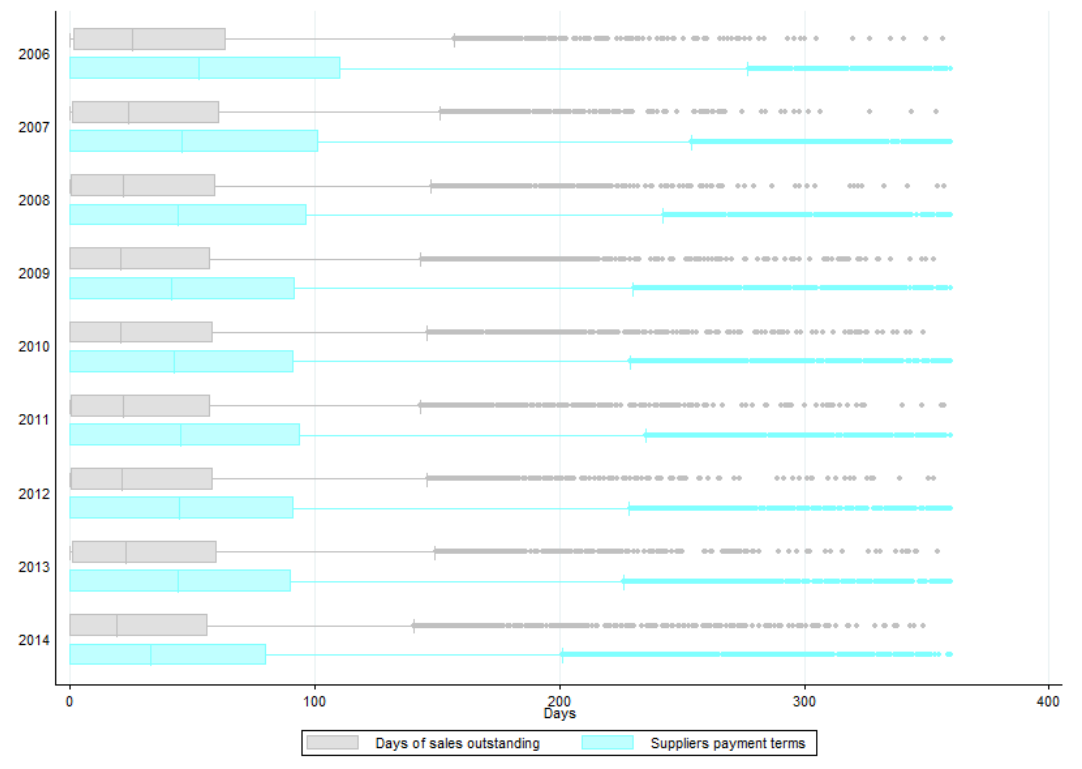

Figure 1: Box plots of inter-enterprises payment deadlines for each year

Even though we have described inter-enterprises payment deadlines over the eighty sectors of our sample (see appendix 2), to better contrast the sectoral distributional characteristics of inter-enterprises payment deadlines, we have gathered the observations according to the four broad sectors of the economy ${ }^{4}$. Figures 2 provides the distributional characteristics of inter-enterprises payment deadlines according to the four broad sectors of economics activities. The quaternary sector has the lowest inter-enterprises payment deadlines. At least $50 \%$ of firms in this sector cashed their customers and paid their suppliers immediately. In contrast, the high-

\footnotetext{
${ }^{4}$ We follow the $20^{\text {th }}$ centery suggestion of economists considering that there are four main economic sectors. The primary sector products raw material. The secondary sector provides finished goods through the raw material. The tertiary sector provides services to the other agents of the economy. The quaternary sector incorporates all activities related to technology, information gathering, media, culture, research and development, and intellectual activities
} 
est inter-enterprises payment deadlines are in the primary and tertiary sectors. The secondary sector has the intermediate inter-enterprises payment deadlines.

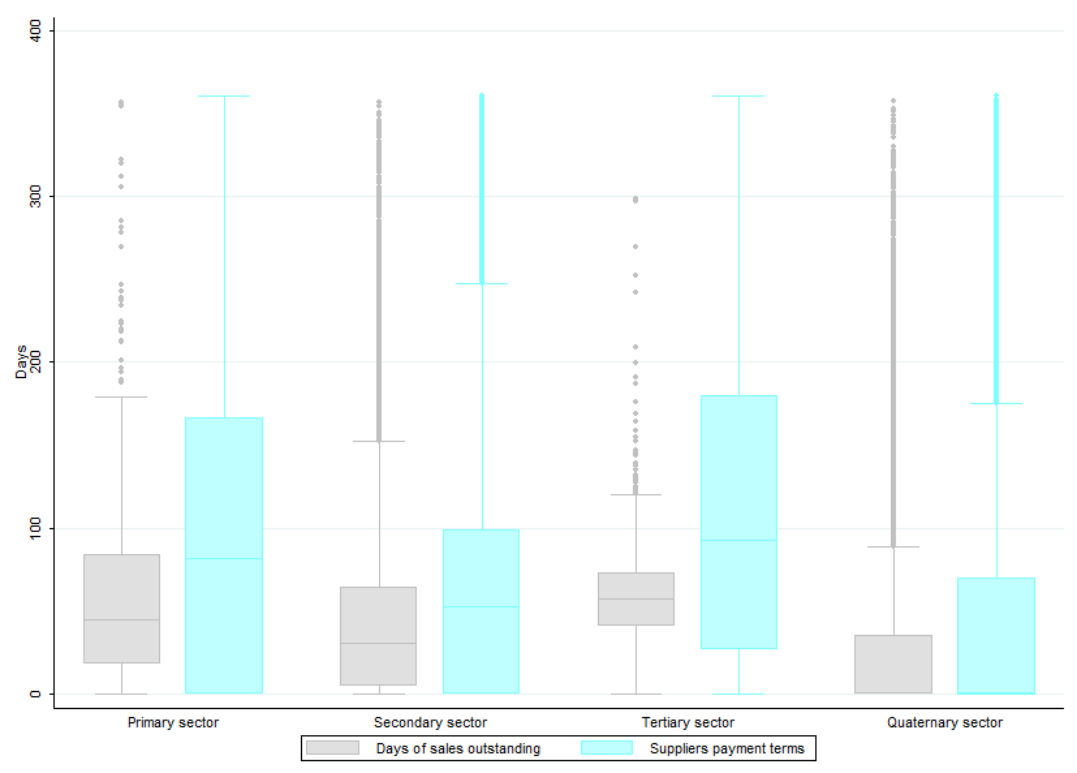

Figure 2: Box plots of inter-enterprises payment deadlines for each broad sector of the economy

In France the inter-enterprises payment deadlines are regulated. In general when two firms conclude a contract, the settlement deadline is set to 60 days. This limit is purely theoretical. In reality, despite the penalties established in case of late payments, many firms exceed 2 months. The non-respect of the regulatory payment terms by some firms leads to gaps between their payment terms. We describe the inter-enterprises payment deadlines by splitting them into 4 categories: those having delays of less than 30 days, between 30 and 60, between 60 and 90 days and more than 90 days. Figure 2 shows firms proportions per days slice. Since 2005, there are more and more firms collecting payments from their customers in 30 days. In 2014, approximately $45 \%$ of firms cashed their customers in less than 30 days compared to $22 \%, 18 \%, 15 \%$ respectively between $30-60,60-90$ and more than 90 days. In parallel, in 2014 , only $15 \%$ of firms paid their suppliers in 30 days. The large majority of firms pay their suppliers between 30-90 days. 


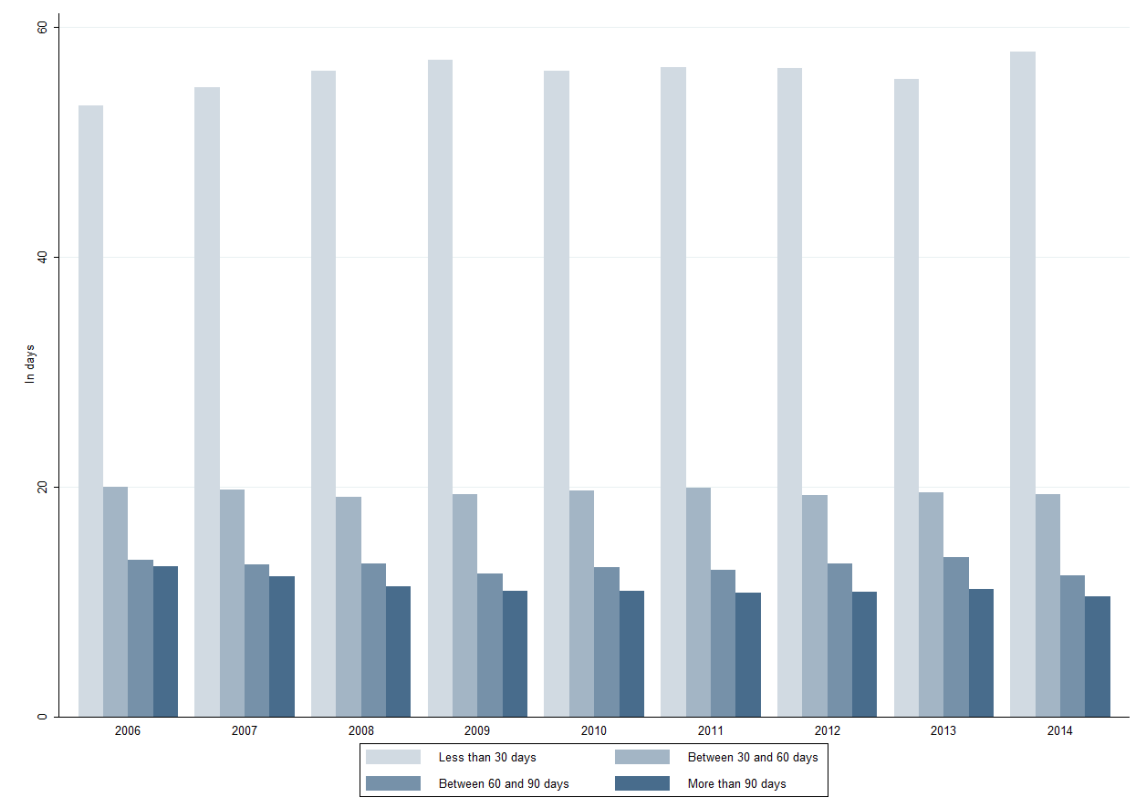

Figure 3: Firms proportion per days of sales outstanding slice

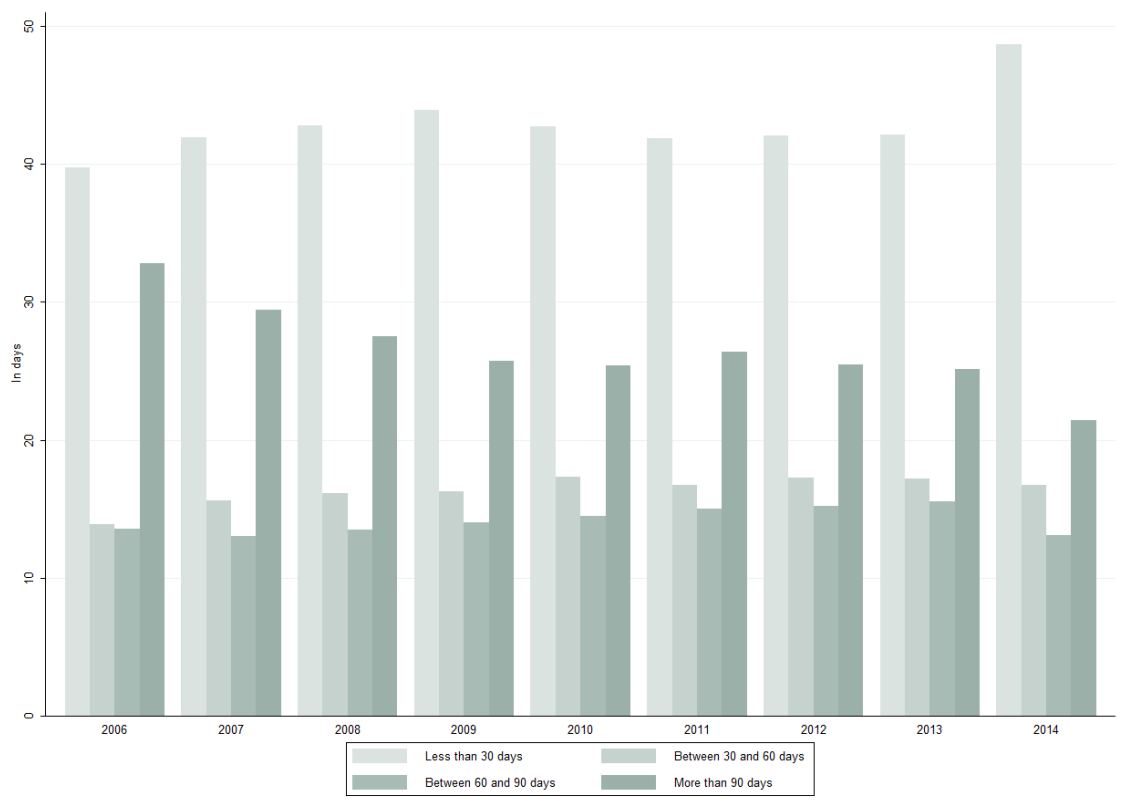

Figure 4: Firms proportion per supplier payment terms slice

This paper uses assets tangibility as initial guess and its median as threshold to conduct the endogenous switching regression model (see section 3.1). Table 5 presents the kernel density and the median of the tangibility ratio by year. We remark that the tangibility ratio is slightly right skewed. The median is not constant but it does not hardly change over time. It is approximatively equal to 0.23. 


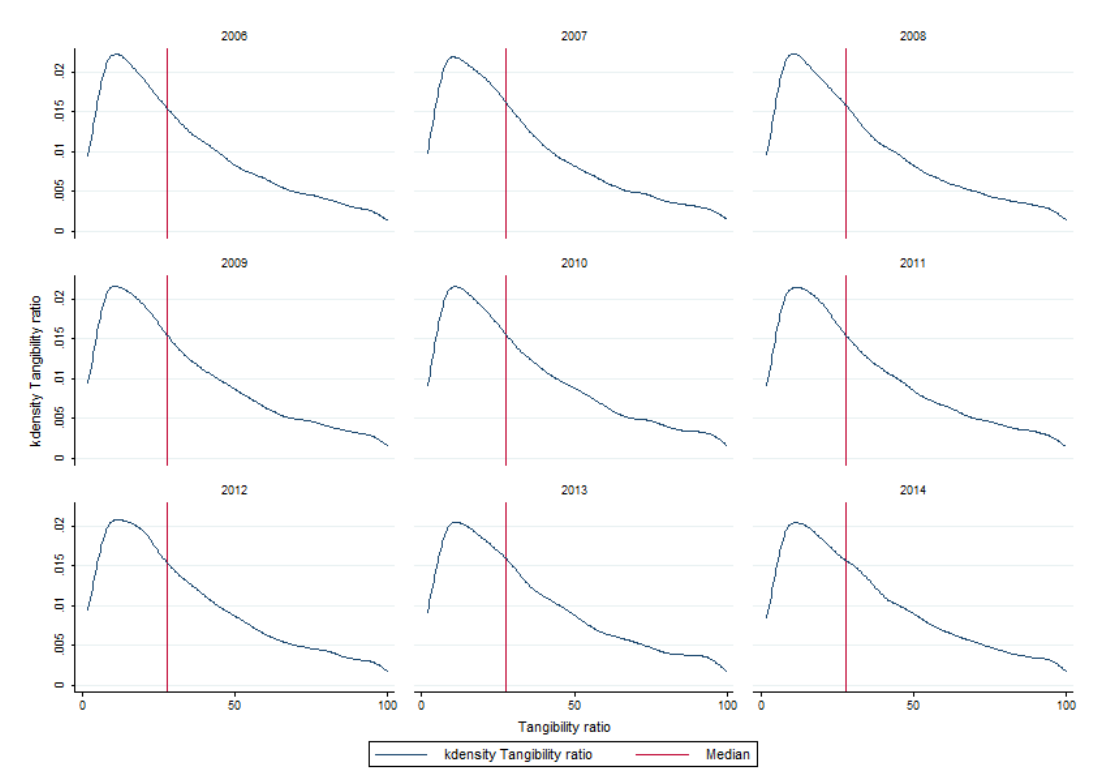

Figure 5: Tangibitliy ratio density

Upstream the estimation, it is interesting to evaluate approximatively the dependence between our key variables. Table 2 provides a preliminary view on the relationship between the main variables through their correlation matrix. Investment is significantly and positively correlated to the cash flow and the suppliers payment terms. It is negatively correlated to the days of sales outstanding. Cash flow displays a significant and positive correlation to the days of sales outstanding and suppliers payment terms.

Table 2: Pairwise correlation coefficients amoung the key variables

\begin{tabular}{lllll}
\hline Variables & Investment & Cash Flow & DSO & SPT \\
\hline \hline Investment & 1 & & & \\
Cash Flow & $0.04^{* *}$ & 1 & & \\
Days of Sales Outstanding (DSO) & $-0.006^{*}$ & $0.08^{* *}$ & 1 & \\
Suppliers payment terms (SPT) & $0.025^{* *}$ & $0.016^{* *}$ & $0.31^{* *}$ & 1 \\
\hline
\end{tabular}

Note that $*, * *$ indicate statistical significance at $1 \%$ and $5 \%$. 


\section{Results}

Tables 3 (3.a and 3.b) reports the maximum likelihood estimation results of the basic endogenous switching regression model specified in section 3.1. All the selection variables have significant coefficients at $5 \%$ level. They play an important role in determining the likelihood of a firm to belong to a particular regime. The estimates indicate that larger, older, highly tangible, leveraged and financially autonomous, less indebted firms are more likely to be unconstrained.

Table 3.b reports the estimation results of the two component equations. We first confirm the previous finding in the existing literature. The investment is positively related to cash flow in both regimes with the estimated coefficient larger in the constrained regime than in the unconstrained one. When an unconstrained firm cash flow increases by one unit, its investment increases by 0.012 unit compared to 0.16 unit for a constrained firm. Inversely, a one unit decrease of an unconstrained firm cash flow implies a decrease of its investment spending by 0.012 unit compared to 0.16 unit when the cash flow decrease concerns a constrained firm.

Secondly, the investment sensitivity to the inter-enterprises payment deadlines is in line with our expectations. The investment is significantly related to interenterprises payment deadlines at $1 \%$ level in both regimes. The investment-days of sales outstanding sensitivity is negative whereas the investment-suppliers payment terms sensitivity is positive. A one day increase in firms days of sales outstanding implies a decrease in unconstrained firms investment spending by $0.003 \%$ compared to $0.012 \%$ in the constrained regime. Inversely, a one day decrease in firms days of sales outstanding implies an increase of unconstrained firms investment spending by $0.003 \%$ compared to $0.012 \%$ in the constrained regime. In parallel, a one day increase in suppliers' payment terms increases unconstrained firms investment by $0.007 \%$ compared to $0.020 \%$ for constrained firms. Inversely, a one day decrease in suppliers' payment terms decreases unconstrained firms investment by $0.007 \%$ compared to $0.020 \%$ for firms in the constrained regime. Thus, a shock on customers or suppliers' payment terms will have on constrained firms investment respectively five times and thrice the effect on unconstrained firms investment. Overall, when customers and suppliers' payment terms increase simultaneously by one day, the unconstrained firms investment increases by $0.004 \%$ compared to $0.008 \%$ for constrained firms.

The gap between the two regimes investment-inter-enterprises payment deadlines sensitivities is caused by unconstrained firms capacity to easily get external funds such as loans or securities issuance to finance their investment whereas the constrained firms can not have access to external funds as they need. So, unconstrained firms do not need a large flexibility from their suppliers to pay their debts and will not be highly limited by a late payment from their customers contrary to constrained 
firms. As long as the maturity of the suppliers debt has not expired, the constrained firms have a period of time during which they will be able to benefit from these cash. In contrast, a late payment represents less liquidity for them.

The initial guess effect on the investment sensitivity to the cash flow and the inter-enterprises payment deadlines were controlled through dummies $D_{1}, D_{2}, D_{3}$ representing respectively tangibility effect on investment-cash flow, investment-days of sales outstanding and investment-suppliers payment terms sensitivities. $D_{1}$ is significant at $1 \%$ level in both the regimes with positive coefficient in the unconstrained regime and negative in the constrained regime. For constrained firms, the higher their tangibility is, the lower the agency conflicts between their stakeholders or informational asymetry will be. Tangible assets decrease their default risks. Then once constrained firms tangibility reaches a certain level, they become unconstrained. These unconstrained firms will invest highly by borrowing in addition to their cash flow. A higher borrowing will increase their default risks and their investment will be highly sensitive to their cash flow as tangibility increases. $D_{2}$ is only significant in constrained group. Indeed, when the constrained firms tangibility ratio increases, their investment sensitivity to the days of sales outstanding increases. Yet, the investment-days of sales outstanding sensitivity is negative. This implies that as well as the tangibility ratio increases, the constrained firms investment is less and less sensitive to the days of sales outstanding. At a certain level of the constrained firms tangibility ratio, they become unconstrained and their investment sensitivity to the days of sales outstanding becomes more lower than when they were constrained. $D_{3}$ is non-significant for both groups. Firms investment sensitivity to suppliers payment terms is not related to the tangibility.

\subsection{Policy implications}

Our findings demonstrate that an increase in inter-enterprises payment deadlines increases firms investment capacity. Some economists propose to reduce inter-enterprises payment deadlines from 60 days to 30 days while some other find that long payment terms are efficient especially in crisis period. We think that inter-enterprises payment deadlines should be regulated to avoid scandalous cases. However an intermediate solution, allowing to control for scandalous payment deadlines on the one hand and giving firms the possibility to benefit from long days of sales outstanding or suppliers payment terms on the other hand, could be found. One solution could be the development and simplification of the factoring. The factoring can be used by both seller and buyer firms, regardless their healthiness or riskiness, to transmit their customers or suppliers invoices to a bank or a factor in order to obtain or allow an immediate payment. 
Table 3: Baseline endogenous switching regression model (see section 3.1)

This table reports the maximum likelihood estimates of the endogenous switching regression model. The reported p-values test the null hypothesis that a single investment regime is sufficient to describe the data as opposed to two regimes. The selection equation estimates are reported in Table 2a. In table $2 \mathrm{~b}$ are reported the two investment equations estmates of the two regimes. These equations are clustering with firms ID and estimated with sector and year dummies. The exogeneity of all our explanatory variables were verified. Note that $* *, *$ indicate respectively the statistical significance at $1 \%$ and $5 \%$.

(a) Selection equation

\begin{tabular}{|c|c|c|}
\hline $\operatorname{LogAge}_{i t-1}$ & $0.37^{* *}$ & 0.002 \\
\hline $\operatorname{Size}_{i t-1}$ & $0.006^{* *}$ & 0.0001 \\
\hline Tangibility $_{i t-1}$ & $0.75^{* *}$ & 0.008 \\
\hline Leverage $_{i t-1}$ & $0.37^{* *}$ & 0.007 \\
\hline $\mathrm{SBC}_{i t-1}$ & $0.03^{* *}$ & 0.006 \\
\hline Fin. Aut $i t-1$ & $0.26^{* *}$ & 0.01 \\
\hline Long term debt $i t-1$ & $-0.16^{* *}$ & 0.06 \\
\hline Constant & $-1.37^{* *}$ & 0.008 \\
\hline
\end{tabular}

(b) Investment equations

\begin{tabular}{|c|c|c|}
\hline \multicolumn{3}{|c|}{ Unconstrained } \\
\hline Variables & Coef & Std \\
\hline $\operatorname{Sales}_{i t-1} / \mathrm{K}_{i t-1}$ & $0.001 * *$ & 0.0001 \\
\hline Cash Flow $_{i t-1} / K_{i t-1}$ & $0.012^{* *}$ & 0.001 \\
\hline LogDays of Sales Outstanding $_{i t-1}$ & $-0.003^{*}$ & 0.001 \\
\hline LogSuppliers Payment Terms $_{i t-1}$ & $0.007^{* *}$ & 0.001 \\
\hline Tangibility $_{i t-1}$ & -0.002 & 0.009 \\
\hline $\mathrm{D}^{*}$ Cash Flow $i t-1 / \mathrm{K}_{i t-1}$ & $0.06^{* *}$ & 0.008 \\
\hline $\mathrm{D}^{*} \log$ Days of Sales Outstanding $i t-1$ & 0.002 & 0.001 \\
\hline $\mathrm{D}^{*} \operatorname{logSuppliers}$ Payment Terms $i t-1$ & -0.002 & 0.001 \\
\hline Constant & 0.05 & 0.03 \\
\hline \multicolumn{3}{|c|}{ Constrained } \\
\hline Variables & Coef & Std \\
\hline $\operatorname{Sales}_{i t-1} / \mathrm{K}_{i t-1}$ & $0.026^{* *}$ & 0.001 \\
\hline Cash Flow $_{i t-1} / K_{i t-1}$ & $0.16^{* *}$ & 0.005 \\
\hline LogDays of Sales Outstanding $i t-1$ & $-0.012^{*}$ & 0.005 \\
\hline LogSuppliers Payment Terms $i t-1$ & $0.020^{* *}$ & 0.006 \\
\hline Tangibility $_{i t-1}$ & $0.13^{* *}$ & 0.02 \\
\hline $\mathrm{D}^{*}$ Cash Flow $i t-1 / \mathrm{K}_{i t-1}$ & $-0.09^{* *}$ & 0.01 \\
\hline $\mathrm{D}^{*} \log$ Days of Sales Outstanding $i t-1$ & $0.03^{* *}$ & 0.005 \\
\hline
\end{tabular}




\begin{tabular}{llc}
$\mathrm{D}^{*} \operatorname{logSuppliers~Payment}$ Terms & & \\
Constant & -0.006 & 0.004 \\
Model P.Value -Likelihood Ratio test- & $-0.25^{* *}$ & 0.04 \\
\hline
\end{tabular}

\subsection{Constrained and unconstrained firms proportions}

The number or firms in the constrained and unconstrained regime are not constant accross the period. Nonetheless the proportions of firms moving from constrained to unconstrained or unconstrained to constrained regimes are not given by the estimation. One solution is to use the estimated selection equation in order to extract the percentage of constrained and unconstrained firms per year.

The selection equation (see equation 3 in section 3 ) is a linear function expressed as:

$$
y_{i t}^{*}=\alpha Z_{i t}+\nu_{i t}
$$

Thus the estimated selection equation is the following: $\overline{y_{i t}^{*}}=\overline{\alpha Z_{i t}^{*}}$

The selection rule was expressed as follows: the firm is financially constrained if $y_{i t}^{*} \geq 0$ and financially unconstrained if $y_{i t}^{*}<0$. Using the estimated results, a firm belongs to the unconstrained regime if $\overline{\alpha Z_{i t}^{*}}<0$ and to the constrained regime if $\overline{\alpha Z_{i t}^{*}} \geq 0$.

Table 4 gives the per year estimated firms proportion in the constrained and unconstrained regimes.

Table 4: Constrained and unconstrained firms proportion per year

\begin{tabular}{lcccccccc}
\hline Variables & 2007 & 2008 & 2009 & 2010 & 2011 & 2012 & 2013 & 2014 \\
\hline Constrained firms(in \%) & 60.6 & 60.2 & 63.3 & 62.4 & 65.1 & 69.8 & 76.04 & 76.8 \\
Unconstrained firms(in \%) & 39.2 & 39.7 & 36.6 & 37.5 & 34.8 & 30.1 & 23.9 & 23.1 \\
\hline
\end{tabular}

We observe an increase in constrained firms proportion since after the financial crisis of 2008. The increase in constrained firms proportion is parallel to the decrease in investment described in section 4 .

Some firms change regime during the period. Figure 2 represents the number of unconstrained firms moving to the constrained regime and vice versa each year. Between 2008-2010, there were about $16 \%$ of firms changing regime each year, against 
approximately $14 \%$ by 2012 . Because of the 2008 crisis, the number of unconstrained firms becoming constrained was increasing. The peak of 3.8\% was reached in 2009 . Since 2010, there are less and less unconstrained firms changing regime.

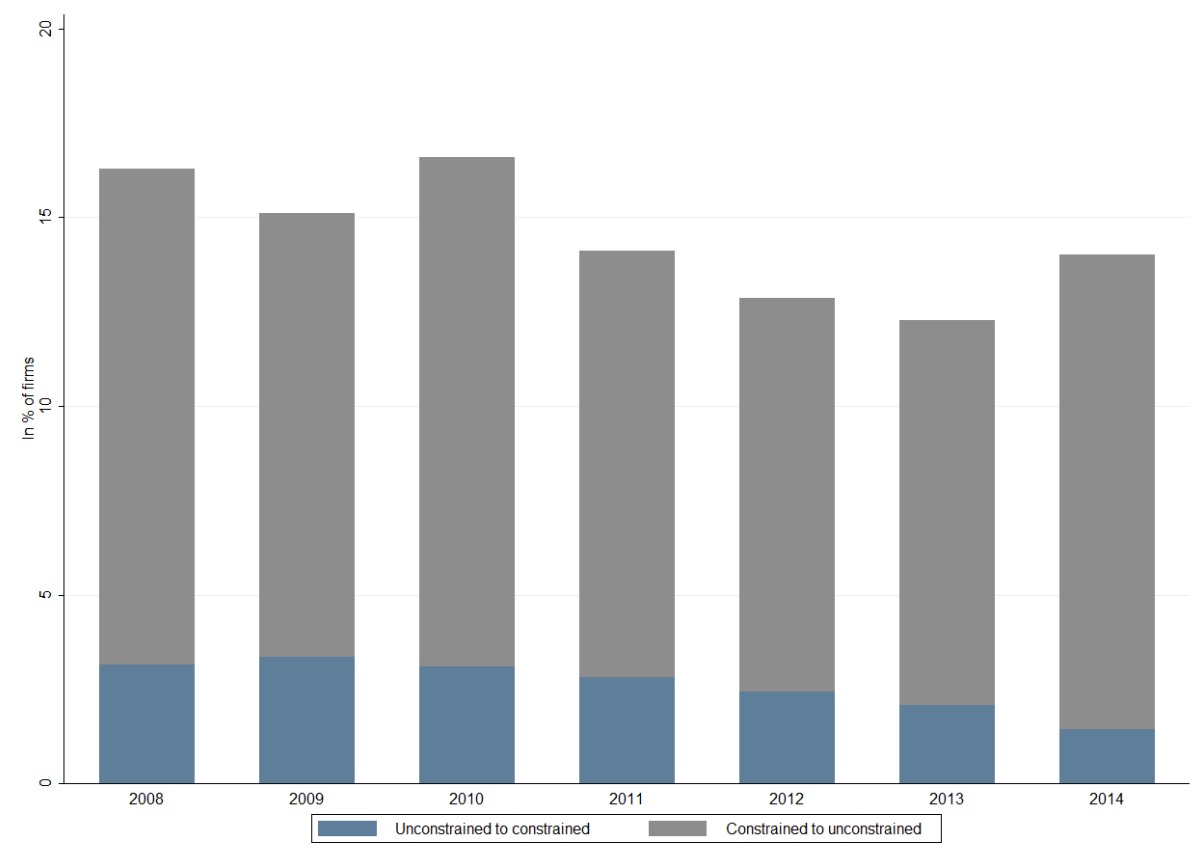

Figure 6: Evolution of firms movement between regimes

\subsection{The determinants of firms status change.}

Through the selection equation the variables determining the firms likelihood to belong to a regime were identified. However, the variables causing the firms regime change from constrained to unconstrained and vice versa remain unknown. In this sub-section, we develop a model for this purpose.

Consider the following equations:

$$
\begin{aligned}
& W_{i t}^{U}=\gamma_{1} \Delta D_{i t}+\nu_{1 i t} \\
& W_{i t}^{C}=\gamma_{2} \Delta D_{i t}+\nu_{2 i t}
\end{aligned}
$$

Equations 7 and 8 estimate respectively the determinants of firms regime change from constrained to unconstrained and inversely. The dependent variable $W^{U}$ and $W^{C}$ are dummies that proxy respectively for the firms regime change from constrained to unconstrained and unconstrained to constrained regimes. $W^{C}$ takes 0 if the firm has not changed regime and 1 if it moves from unconstrained regime at time $t$ to 
constrained regime at $\mathrm{t}+1$. $W^{U}$ takes 0 if the firm has not changed regime and 1 if it moves from constrained regime at time t to unconstrained regime at $\mathrm{t}+1 . \Delta D$ is the set of explanatory variables. It is composed by the variation of each variable used in the switching regression model except investment because of its endogeneity. We add also the interest coverage ratio that we have not used in the switching regression estimation but was used in past literature. The overall considered explanatory variables are sales, cash flow, days of sales outstanding suppliers payment terms, tangibility, size, soft budget constraint, leverage, long-term debt, ratio of financial autonomy and the interest coverage ratio. We performed a logit regression to estimate this equation.

Tables 6 reports the estimated results. They reveal that size, tangibility, leverage, long-term debt, soft budget constraint, and financial autonomy are the factors influencing constrained firms status change to the unconstrained regime. More constrained firms size, tangibility, leverage, long-term debt, soft budget constraint, or financial autonomy increases more their financial constraints decrease, and more they become unconstrained. In contrast, more constrained firms size, tangibility, leverage, long-term debt, soft budget constraint, or financial autonomy decreases, more their constrained status does not change.

On the other hand, tangibility, leverage, soft budget constraint, and financial autonomy are the factors influencing unconstrained firms regime change to the constrained regime. More unconstrained firms tangibility, leverage, soft budget constraint, or financial autonomy decreases, more they face financial constraints, and more they become constrained. In contrast, more unconstrained firms tangibility, leverage, soft budget constraint, or financial autonomy increases, more their unconstrained status does not change.

Long-term debt does not influence unconstrained firms regime change to the constrained regime while it influences constrained firms regime change to the unconstrained regime. One possible reason is that a decrease of an unconstrained firm's long-term debt does not necessary mean that the firm faces financial constraints. Most of the times, it is simply unconstrained firms choice to reduce their long-term debt. However, an increase of constrained firms long-term debt indicates mostly that they do not face credit rationing any more.

Size influences constrained firms regime change to the unconstrained regime while it does not influence unconstrained firms regime change to the constrained regime. The reason is that a decrease of unconstrained firms size is not an indicator of their riskiness or healthiness. Some employee may leave their jobs because they reached the end of their contract. Although, when constrained firms hiring rate increases, it mostly means that their constrained status has decreased or vanished.

Cash flow, days of sales outstanding, suppliers payment terms, and interest cov- 
erage rate do not influence neither constrained firms regime change to the unconstrained regime nor unconstrained firms regime change to the constrained regime. We found in section 4.2 that cash flow, days of sales outstanding, and suppliers payment terms are factors determining firms investment financing constraints. This could be the reason why they are not determinants of firms status change.

Table 5: Determinants of firms status change

\begin{tabular}{|c|c|c|c|c|}
\hline & \multicolumn{2}{|c|}{ Const. to Unconst. } & \multicolumn{2}{|c|}{ Unconst. to Const. } \\
\hline & Coef & Std & Coef & Std \\
\hline$\Delta$ Salesit & -0.00005 & 0.00003 & -0.00003 & 0.00004 \\
\hline$\Delta$ Cashflow $_{i t}$ & 0.0002 & 0.0003 & 0.00008 & 0.0003 \\
\hline$\Delta$ Daysof salesoutstanding $_{i t}$ & 0.0005 & 0.001 & 0.00008 & 0.0003 \\
\hline$\Delta$ Supplierspaymentterms $s_{i t}$ & 0.0007 & 0.0005 & 0.001 & 0.001 \\
\hline$\Delta S i z e_{i t}$ & $0.03^{* *}$ & 0.01 & -0.01 & 0.01 \\
\hline$\Delta$ Tangibility $_{i t}$ & $1.66^{* *}$ & 0.4 & $-1.93^{*}$ & 0.43 \\
\hline$\Delta$ Leverage $_{i t}$ & $0.80^{* *}$ & 0.19 & $-1.34^{* *}$ & 0.27 \\
\hline$\Delta$ Long - termdebt $_{i t}$ & $0.0002^{*}$ & 0.0001 & -0.00006 & 0.0001 \\
\hline$\Delta$ SoftBudgetConstraint $_{i t}$ & $0.25^{*}$ & 0.1 & $-0.50 * *$ & 0.08 \\
\hline$\Delta$ Fin.Autonomy $y_{i t}$ & $1.17^{* *}$ & 0.36 & $-2.01^{* *}$ & 0.47 \\
\hline$\Delta$ Int.Cov.Ratio ${ }_{i t}$ & -2.65 & 3.75 & -0.76 & 4.8 \\
\hline
\end{tabular}

Note: The interest coverage ratio is the ratio between the interest expenses and the EBITDA. Note that $* *, *$ indicate respectively the statistical significance at $1 \%$ and $5 \%$. 


\section{Conclusion}

The existing literature studying the determinants of firms investment financing constraints widely investigates the investment sensitivity to the cash flow. Yet, the cash flow as defined in the literature does not include the receivables from the customers and trade payables which are important firms financing sources. This paper provides a relevant complement to the existing literature by considering the business to business credits as part of the cash flow. The B2B credits generate days of sales outstanding and suppliers payment terms. In this paper, we assume that they could impact firms investment.

Between 2005 and 2014, our sample of firms from Provence-Alpes Côte d'Azur region (PACA) provides evidence that as cash flow, the inter-enterprises payment deadlines are significant determinants of firms investment. Firms investment is negatively sensitive to days of sales outstanding whereas it is positively sensitive to suppliers payment terms. The study being conducted on firms classified in constrained and unconstrained regimes, we found that the constrained firms investment is more sensitive to inter-enterprises payment deadlines than that of unconstrained firms.

By conducting this study on PACA region firms, we provide a novel index of financing constraints for SMEs. Indeed, in this region 99\% of firms are SMEs. Yet, most of the studies on firms investment financing constraints are conducted on large firms. The SMEs are more concerned by financing constraints than large firms. Furthermore, this empirical study is conducted using an endogenous switching regression model. If this model allows a non-priori classification of firms in constrained and unconstrained regimes, it does not give to the researcher information on the constrained and uncontrained firms behavior. In this paper, we exploit the selection equation to determine the proportions of firms in each regime. Remarking that, these proportions are not constant over year, we develop a model allowing to extract the number of firms changing regime each year and the reason why they change regime. 


\section{References}

[1] Adelegan, O., and Ariyo, A., 2008. Capital market imperfections and corporate investment behavior: A switching regression approach using panel data for Nigerian manufacturing firms, Journal of Money, Investment and Banking 2, 16-38.

[2] Almeida, H., and Campello, M., 2007. Financial Constraints, Asset Tangibility, and Corporate Investment, Review of Financial Studies 20(5), 1429-1460.

[3] Almeida, H., Campello, M., and Galvao, F., 2010. Measurement Errors in Investment Equations, Review of Financial Studies 23(9), 3279-3328.

[4] Bernanke, B., Gertler, M., and Gilchrist, S., 1996, The Financial Accelerator and the Flight to Quality, Review of Economics and Statistics 78, 1-15.

[5] Bond, S., and Meghir, C., 1994, Dynamic Investment Models and the Firm's Financial Policy, The Review of Economic Studies, 197-222.

[6] Bond, S., Elston, J., Mairesse, J., and Mulkay B., 2003. Financial Factors and Investment in Belgium, France, Germany, and the United Kingdom: A Comparison using Company Panel Data. The Review of Economics and Statistics 85(1), 153-165.

[7] Calomiris, C., Himmelberg, C., and Wachtel, P., 1995. Commercial paper, corporate nance, and the business cycle: A microeconomic perspective. CarnegieRochester Conference Series on Public Policy 42, 203-250

[8] Chirinko, R., S., 1993. Business Fixed Investment Spending : Modelling Strategies, Empirical Results, and Policy Implications. Journal of Economic Literature 31(4) 1875-1911.

[9] Cleary S., 1999. The relationship between rm investment and nancial status. The Journal of Finance 54(2), 673-692.

[10] Ding, S., Guariglia, A., Knight, J., 2013. Investment and financing constraints in China: Does working capital management make a difference?. Journal of Banking G Finance 37, 1490-1507.

[11] Eisner, R., 1978, Cross Section and Time Series Estimates of Investment Functions. Annales de l'INSEE 30/31, 99-129.

[12] Fazzari, S. M., Hubbard, R. G., and Petersen, B. C., 1988. Financing Constraints and Corporate Investment. Brookings Papers on Economic Activity 1988(1), $141-206$. 
[13] Gianni La Cava, 2005. Financial Constraints, The User Cost of Capital and Corporate Investment in Australia. Reserve Bank of Australia Economic Discussion Paper.

[14] Gilchrist, S., and Himmelberg, C. P., 1995. Evidence on the role of cash flow on investment. Journal of Monetary Economics 36(3), 541-572.

[15] Hobdari, B., Jones, D. C., and Mygind, N., 2009. Capital investment and determinants of nancial constraints in Estonia. Economic Systems 33(4), 344-359

[16] Hoshi, T., Kashyap ,A., Scharfstein, D., 2009. Corporate Structure, Liquidity, and Investment: Evidence from Japanese Industrial Groups. The Quarterly Journal of Economics 106(1), 33-60.

[17] Hovakimian, G. and Titman, S., 2006. Corporate investment with nancial constraints: Sensitivity of investment to funds from voluntary asset sales. Journal of Money Credit and Banking 38(2), 357-374.

[18] Hovakimian, G., 2009. Determinants of investment cash ow sensitivity. Financial Management 38(1), 161-183.

[19] Hu, X., and Schiantarelli, F., 1998. Investment and capital market imperfections: A switching regression approach using US rm panel data. The Review of Economics and Statistics 80(3), 466-479.

[20] Hubbard, R. G., 1998. Capital-Market Imperfections and Investments. Journal of Economic Literature 36(1), 193-225.

[21] Jorgenson, D. W., 1963. Capital Theory and Investment Behavior. The American Economic Review 53(2), 247-259.

[22] Kaplan, S. N., and Zingales, L., 1997. Do Investment-Cash Flow Sensitivities Provide Useful Measures of Financing Constraints. The Quarterly Journal of Economics 112(1), 169-215.

[23] Modigliani, F., and Miller, M. H., 1958. The Cost of Capital, Corporation Finance, and the Theory of Investment. The American Economic Review 48(3), 261-297.

[24] Nathalie Moyen, 2004. Investment-cash Flow Sensitivities: Constrained versus Unconstrained Firms. The Journal of Finance 59(5), 2061-2092.

[25] Mulkay, B., Hall, B.H., and Mairesse, J., 2001. Investissement des entreprises et contraintes financières en France et aux Etats-Unis. Economie et Statistique 341-342, 67-89. 
[26] Myers, S. C., 1977. Determinants of corporate borrowing. Journal of Financial Economics 5(2), 147-175.

[27] Myers, S. C., and Majluf, N. S., 1984. Corporate Financing and Investment Decisions When Firms Have Information That Investors Do Not Have. Journal of Financial Economics 13(2), 187-221.

[28] Quader, M., and Taylor, K., 2014. Corporate Efficiency, Credit Status, and Investment. IZA Discussion Paper 8285.

[29] Schiantarelli, F., 1996. Financial Constraints in Investment: Methodological Issues and International Evidence. Oxford Review of Economic Policy 12(2), 70-89.

[30] Stiglitz, J. E., 1973. Taxation, Corporate Financial Policy and the Cost of Capital. Journal of Public Economics 2(1), 1-34.

[31] Stiglitz, J. E., and Weiss, A., 1981. Credit Rationing in Markets with Imperfect Information. The American Economic Review 71(3), 393-410.

[32] Tobin, J., 1969. A General Equilibrium Approach to Monetary Theory. Journal of Money, Credit and Banking 1(1), 15-29.

[33] Whited, T. M., 1992. Debt, Liquidity Constraints and Corporate Investment: Evidence from Panel Data. Review of Financial Studies 19(2), 531-559. 


\section{Appendix 1: Robustness check}

Because of the initial guess, we made a robustness check in verifying and adressing potential biases in our results. We repeated the estimation by changing the initial guess. We replaced it by the Return on Capital Employed (ROCE). It measures a firm's profitability and the efficiency with which its capital is employed. In this case, we choose a threshold by sector to create the initial guess. We assumed that firms with a ROCE less than the median ROCE by sector are more "likely" to be financially constrained and inversely. The estimated results (see Table 7) of the key variables are found to be robust.

Table 6: Endogenous switching regression model with ROCE

Note that $* *, *$ indicates respectively the statistical significance at $1 \%$ and $5 \%$ level

(a) Selection equation

\begin{tabular}{|c|c|c|}
\hline Variables & Coef & Std \\
\hline Variables & Coef & Std \\
\hline $\operatorname{LogAge}_{i t-1}$ & $0.38^{* *}$ & 0.001 \\
\hline Size $_{i t-1}$ & $0.0006^{* *}$ & 0.0001 \\
\hline $\mathrm{ROCE}_{i t-1}$ & $-0.11^{* *}$ & 0.0009 \\
\hline Leverage $_{i t-1}$ & $0.3^{* *}$ & 0.005 \\
\hline Long term debt ${ }_{i t}$ & $-0.31^{* *}$ & 0.05 \\
\hline $\mathrm{SBC}_{i t-1}$ & $0.07^{* *}$ & 0.004 \\
\hline Fin.Aut $_{i t-1}$ & $0.001^{* *}$ & $3.26 \mathrm{e}-06$ \\
\hline Constant & $-1.05^{* *}$ & 0.005 \\
\hline
\end{tabular}

(b) Investment equations

\begin{tabular}{llc}
\hline \multicolumn{2}{c}{ Unconstrained } & \\
\hline Variables & Coef & Std \\
\hline Sales $_{i t-1} / \mathrm{K}_{i t-1}$ & $0.001^{* *}$ & 0.0001 \\
Cash Flow $_{i t-1} / K_{i t-1}$ & $0.009^{* *}$ & 0.002 \\
LogDays of Sales Outstanding $_{i t-1}$ & $-0.003^{*}$ & 0.0009 \\
LogSuppliers Payment Terms $_{i t-1}$ & $0.006^{* *}$ & 0.001 \\
$\mathrm{ROCE}_{i t-1}$ & 0.003 & 0.002 \\
$\mathrm{D}^{*}$ Cash Flow $_{i t-1} / \mathrm{K}_{i t-1}$ & 0.0008 & 0.003 \\
$\mathrm{D}^{*} \operatorname{logDays~of~Sales~Outstanding~}_{i t-1}$ & 0.001 & 0.001 \\
$\mathrm{D}^{*} \operatorname{logSuppliers~Payment~Terms~}_{i t-1}$ & 0.001 & 0.001 \\
Constant & $0.02^{*}$ & 0.013 \\
\hline \multicolumn{2}{c}{ Constrainted } \\
Variables & Coef & Std \\
\hline
\end{tabular}




\begin{tabular}{|c|c|c|}
\hline $\operatorname{Sales}_{i t-1} / \mathrm{K}_{i t-1}$ & $0.02^{* *}$ & 0.001 \\
\hline Cash Flow $_{i t-1} / K_{i t-1}$ & $0.16^{* *}$ & 0.016 \\
\hline LogDays of Sales Outstanding $i t-1$ & $-0.015^{* *}$ & 0.003 \\
\hline LogSuppliers Payment Terms $i t-1$ & $0.027^{* *}$ & 0.005 \\
\hline $\mathrm{ROCE}_{i t-1}$ & $-0.01^{* *}$ & 0.004 \\
\hline $\mathrm{D}^{*} \operatorname{Cash~Flow~}_{i t-1} / \mathrm{K}_{i t-1}$ & -0.03 & 0.02 \\
\hline $\mathrm{D}^{*} \log$ Days of Sales Outstanding $i t-1$ & $0.01^{* *}$ & 0.006 \\
\hline $\mathrm{D}^{*} \operatorname{logSuppliers}$ Payment Terms $i t-1$ & -0.14 & 0.004 \\
\hline Constant & -0.06 & 0.04 \\
\hline Model P.Value -Likelihood Ratio test- & 0.000 & \\
\hline
\end{tabular}




\section{Appendix 2: Descriptive statistics by sector}

Table 7: Number of observations by sector according to the French Classification of Activities (NAF rev.2)

\begin{tabular}{|c|c|c|c|c|c|}
\hline Code & Observations & Code & Observations & Code & Observations \\
\hline 01 & 628 & 37 & 67 & 77 & 527 \\
\hline 02 & 56 & 38 & 243 & 78 & 4 \\
\hline 03 & 5 & 39 & 3 & 79 & 65 \\
\hline 08 & 53 & 41 & 926 & 80 & 176 \\
\hline 09 & 4 & 42 & 383 & 81 & 3345 \\
\hline 10 & 3706 & 43 & 24608 & 82 & 483 \\
\hline 11 & 162 & 45 & 8741 & 85 & 543 \\
\hline 13 & 220 & 46 & 12017 & 86 & 1308 \\
\hline 14 & 141 & 47 & 25518 & 87 & 217 \\
\hline 15 & 84 & 49 & 851 & 88 & 45 \\
\hline 16 & 375 & 50 & 25 & 90 & 242 \\
\hline 17 & 90 & 51 & 11 & 91 & 26 \\
\hline 18 & 796 & 52 & 133 & 92 & 6 \\
\hline 19 & 7 & 53 & 5 & 93 & 331 \\
\hline 20 & 693 & 55 & 2436 & 94 & 9 \\
\hline 21 & 19 & 56 & 12875 & 95 & 855 \\
\hline 22 & 353 & 58 & 313 & 96 & 4960 \\
\hline 23 & 612 & 59 & 71 & 99 & 2 \\
\hline 24 & 44 & 60 & 4 & & \\
\hline 25 & 1569 & 61 & 161 & & \\
\hline 26 & 392 & 62 & 975 & & \\
\hline 27 & 243 & 63 & 85 & & \\
\hline 28 & 476 & 64 & 460 & & \\
\hline 29 & 201 & 65 & 1 & & \\
\hline 30 & 65 & 66 & 39 & & \\
\hline 31 & 394 & 68 & 1055 & & \\
\hline 32 & 1129 & 72 & 71 & & \\
\hline 33 & 2241 & 73 & 484 & & \\
\hline 35 & 28 & 74 & 524 & & \\
\hline 36 & 43 & 75 & 181 & & \\
\hline
\end{tabular}

${ }^{1}$ Note: The column code gives the code assigned by INSEE to each activity in the French Classification of Activities level 2 (NAF rev.2). 


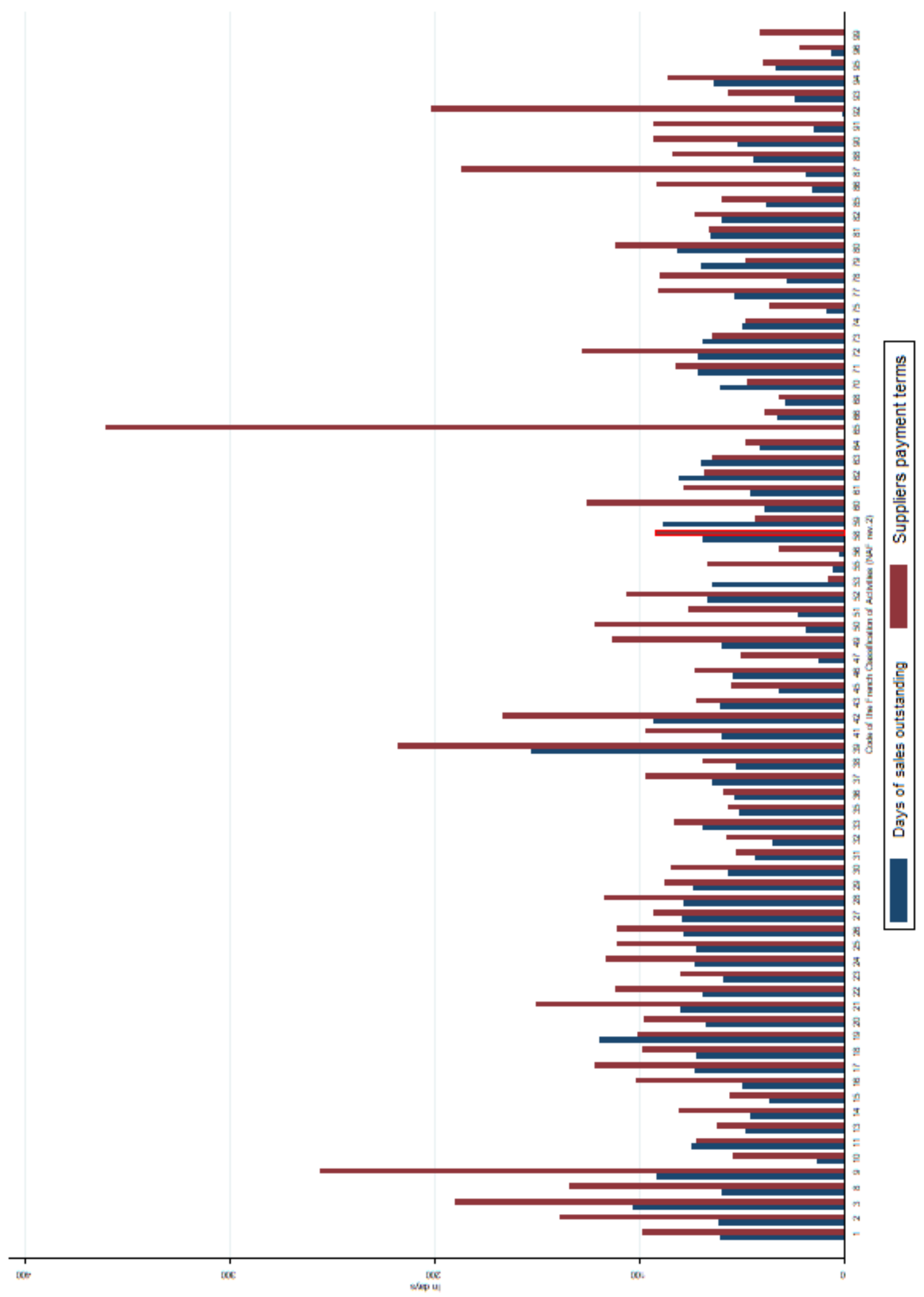

Figure 7: Inter-enterprises payment deadlines per sector according to the French Classification of Activities (NAF rev.2) 


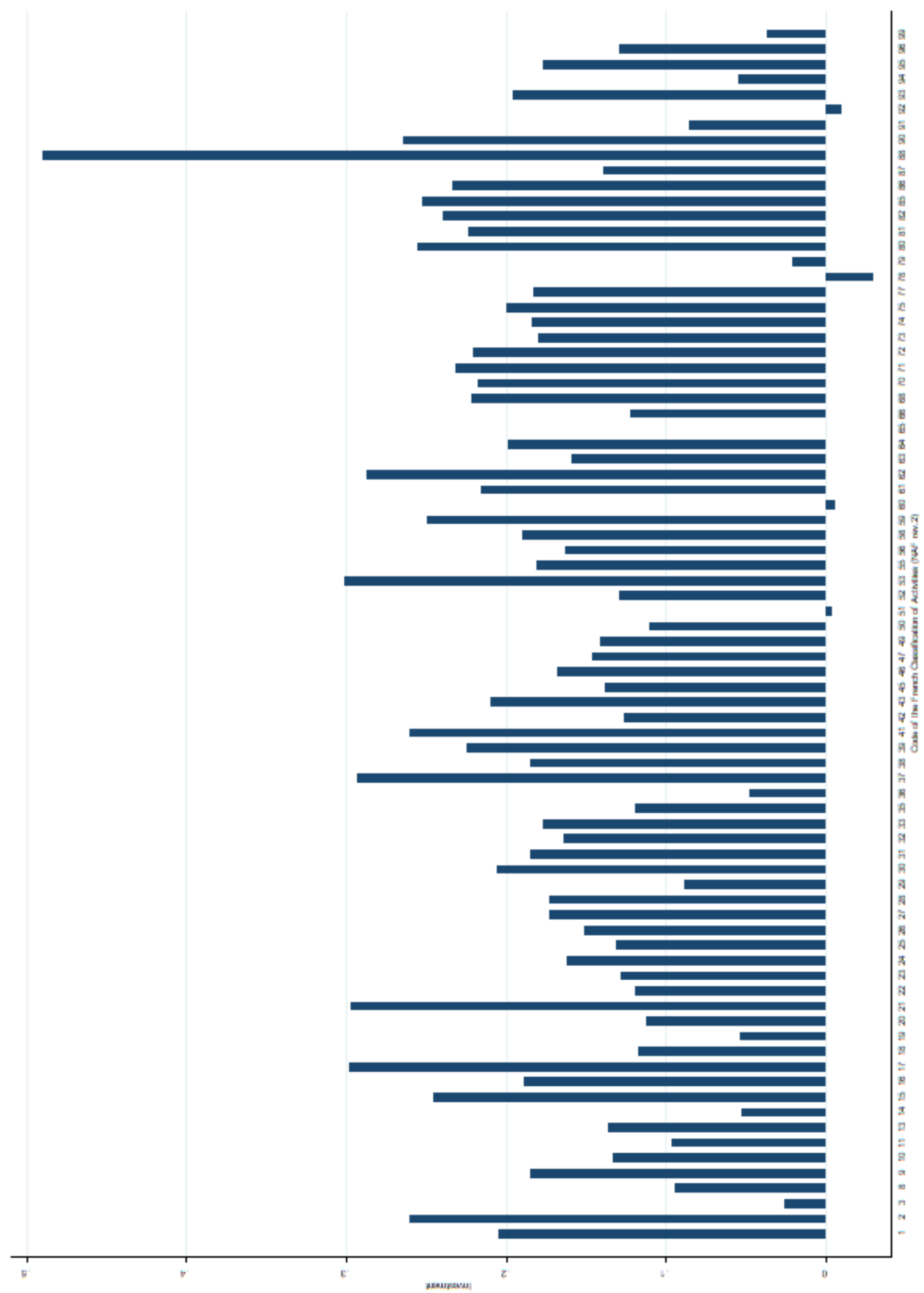

Figure 8: Investment per sector according to the French Classification of Activities (NAF rev.2) 
Table 8: Labels of the French Classification of Activities codes (NAF rev.2)

\begin{tabular}{|c|c|c|c|}
\hline Code & Label & Code & Label \\
\hline 01 & Crop and animal production, & 56 & Food \\
\hline 02 & Forestry and logging & 58 & Edition \\
\hline 03 & Fishing and aquaculture & 59 & $\begin{array}{l}\text { Production of motion pictures } \\
\text { video and television programs } \\
\text { sound recording and music pub- } \\
\text { lishing }\end{array}$ \\
\hline $\begin{array}{l}05 \\
06\end{array}$ & $\begin{array}{l}\text { Extraction of coal and lignite } \\
\text { Extraction of hydrocarbons }\end{array}$ & 60 & Programming and dissemination \\
\hline 07 & Extraction of metal ores & 62 & Programming, consulting and \\
\hline 08 & Other mining and quarrying & 63 & $\begin{array}{l}\text { other IT activities } \\
\text { Information Services }\end{array}$ \\
\hline 09 & $\begin{array}{l}\text { Extractive Industries Support Ser- } \\
\text { vices }\end{array}$ & 64 & Financial services activities, ex- \\
\hline 10 & Food industries & 65 & Insurance \\
\hline 11 & Beverage manufacturing & 66 & Auxiliary activities in financia \\
\hline $\begin{array}{l}12 \\
13\end{array}$ & $\begin{array}{l}\text { Manufacture of tobacco products } \\
\text { Textile manufacturing }\end{array}$ & $\begin{array}{l}68 \\
69\end{array}$ & $\begin{array}{l}\text { Real estate activities } \\
\text { Legal and accounting activities }\end{array}$ \\
\hline 14 & Clothing industry & 70 & $\begin{array}{l}\text { Activities of head offices; manage- } \\
\text { ment consultancy }\end{array}$ \\
\hline 15 & Leather and footwear industry & 71 & $\begin{array}{l}\text { Architectural and engineering ac- } \\
\text { tivities; control activities and tech- } \\
\text { nical analysis }\end{array}$ \\
\hline 16 & $\begin{array}{l}\text { Woodworking and manufacture of } \\
\text { articles of wood and cork, except } \\
\text { furniture; manufacture of articles } \\
\text { of straw and plaiting }\end{array}$ & 72 & $\begin{array}{l}\text { Scientific research and develop- } \\
\text { ment }\end{array}$ \\
\hline 17 & Paper and paperboard industry & 73 & Advertising and market research \\
\hline 18 & Printing and reproduction of & 74 & Other specialized, scientific and \\
\hline $\begin{array}{l}19 \\
20 \\
21\end{array}$ & $\begin{array}{l}\text { Coking and refining } \\
\text { Chemical industry } \\
\text { Pharmaceutical industry }\end{array}$ & $\begin{array}{l}75 \\
77 \\
78\end{array}$ & $\begin{array}{l}\text { Veterinary activities } \\
\text { Rental and leasing activities } \\
\text { Employment-related activities }\end{array}$ \\
\hline 22 & $\begin{array}{l}\text { Rubber and plastic products man- } \\
\text { ufacturing }\end{array}$ & 79 & $\begin{array}{l}\text { Activities of travel agencies, tour } \\
\text { operators, reservation services and } \\
\text { related activities }\end{array}$ \\
\hline 23 & $\begin{array}{l}\text { Other non-metallic mineral prod- } \\
\text { uct manufacturing }\end{array}$ & 80 & Investigations and security \\
\hline 24 & Metallurgy & 81 & $\begin{array}{l}\text { Services related to buildings and } \\
\text { landscaping }\end{array}$ \\
\hline 82 & $\begin{array}{l}\text { Administrative activities and } \\
\text { other business support activities }\end{array}$ & & \\
\hline 25 & $\begin{array}{l}\text { Manufacture of metal products, } \\
\text { except machinery and equipment }\end{array}$ & 84 & $\begin{array}{l}\text { Public administration and defense } \\
\text { compulsory social security }\end{array}$ \\
\hline 26 & $\begin{array}{l}\text { Computer, electronic and optical } \\
\text { product manufacturing }\end{array}$ & 85 & Education \\
\hline 27 & $\begin{array}{l}\text { Manufacture of electrical equip- } \\
\text { ment }\end{array}$ & 86 & Activities for human health \\
\hline 28 & $\begin{array}{l}\text { Manufacture of machinery and } \\
\text { equipment n.e.c. }\end{array}$ & 87 & Medico-social and social housing \\
\hline 29 & Automotive Industry & 88 & $\begin{array}{l}\text { Social action without accommoda- } \\
\text { tion }\end{array}$ \\
\hline 30 & $\begin{array}{l}\text { Manufacture of other transport } \\
\text { equipment }\end{array}$ & 90 & $\begin{array}{l}\text { Creative, arts and entertainment } \\
\text { activities }\end{array}$ \\
\hline 31 & Manufacture of furniture & 91 & $\begin{array}{l}\text { Libraries, Archives, Museums and } \\
\text { Other Cultural Activities }\end{array}$ \\
\hline 32 & Other manufacturing industries & 92 & $\begin{array}{l}\text { Organization of games of chance } \\
\text { and money }\end{array}$ \\
\hline 33 & $\begin{array}{l}\text { Repair and installation of machin- } \\
\text { ery and equipment }\end{array}$ & 93 & $\begin{array}{l}\text { Sports, recreation and leisure ac- } \\
\text { tivities }\end{array}$ \\
\hline
\end{tabular}


35 Production and distribution of electricity, gas, steam and air conditioning

36 Collection, treatment and distribution of water 37 Collection and treatment of

38 Collection, treatment and disposal of waste; recovery

39 Remediation and other waste management services

41 Construction of buildings

$42 \quad$ Civil Engineering

$43 \quad$ Specialized construction work

$45 \quad$ Trade and repair of motor vehicles and motorcycles

46 Wholesale trade, except of motor vehicles and motorcycles

47 Retail trade, except of motor vehicles and motorcycles

$49 \quad$ Land transport and pipeline transport

$50 \quad$ Water transport

$51 \quad$ Air transport

52 Warehousing and auxiliary transport services

53 Post and courier activities

55 Accommodation
94 Activities of community organizations

Repair of computers and personal and household goods Other personal services Household activities as employers of domestic staff Undifferentiated activities of households as producers of goods and services for their own use nizations and bodies 